\title{
lodine insufficiency in pregnant women from the State of São Paulo
}

\author{
Insuficiência iódica em gestantes paulistas
}

Sabrina Maria Saueia Ferreira', Anderson Marliere Navarro², Patrícia Künzle Ribeiro Magalhães', Léa Maria Zanini Maciel'

${ }^{1}$ Divisão de Endocrinologia, Departamento de Clínica Médica, Faculdade de Medicina de Ribeirão Preto, Universidade de São Paulo (FMRP-USP),

Ribeirão Preto, SP, Brazil

2 Divisão de Nutrição,

Departamento de Clínica Médica,

FMRP-USP, Ribeirão Preto, SP, Brazi

This study was developed at the School of Medicine of Ribeirão Preto, Universidade de São Paulo (FMRP-USP).

Correspondence to: Léa Maria Zanini Maciel Departamento de Clínica Médica, Faculdade de Medicina de Ribeirão Preto, Universidade de São Paulo Av. Bandeirantes, 3900 14049-900 - Ribeirão Preto, SP, Brazil Imzmacie@fmrp.usp.br

Received on Sept/9/2013 Accepted on Nov/15/2013

\begin{abstract}
Objective: The intake of adequate amounts of iodine during pregnancy is essential for the neurological development of the fetus. The aim of this study was to assess iodine nutrition status in pregnant women from the state of São Paulo, Brazil. Material and methods: We analyzed urinary iodine concentration (UIC) in 191 pregnant and 58 non-pregnant women matched by age. We used the World Health Organization criteria to define sufficient iodine supply (median UIC: 150-249 $\mu \mathrm{g} / \mathrm{L}$ among pregnant women, and 100-199 $\mu \mathrm{g} / \mathrm{L}$ for non-pregnant women). Results: Median UIC of the pregnant women studied was lower than the recommended value (median $=137.7 \mu \mathrm{g} / \mathrm{L}, 95 \% \mathrm{Cl}=132.9-155.9$ ), while non-pregnant women had UIC levels within the appropriate range $($ median $=190 \mu \mathrm{g} / \mathrm{L} ; 95 \% \mathrm{IC}=159.3-200.1)$. UIC was below $150 \mu \mathrm{g} / \mathrm{L}$ in $57 \%$ of the pregnant women. Conclusions: Although a larger sample is needed to consolidate these findings, these results raise concerns about the adequacy of the iodine supply of pregnant women in Brazil, especially considering the new determinations of the Brazilian government, which have recently reduced the concentrations of iodine in table salt to $15-45 \mathrm{mg} / \mathrm{kg}$ of salt. Arq Bras Endocrinol Metab. 2014;58(3):282-7
\end{abstract}

\section{Keywords}

Urinary iodine; iodine sufficiency; thyroid; pregnancy; Brazil

\section{RESUMO}

Objetivo: O consumo de quantidade adequada de iodo durante a gestação é de fundamental importância para o desenvolvimento neurológico do feto. $O$ objetivo deste estudo foi avaliar o estado nutricional iódico em gestantes do estado de São Paulo, Brasil. Material e métodos: Analisamos a concentração urinária de iodo (UIC) em 191 gestantes e em 58 mulheres não gestantes de mesma faixa etária. Foram utilizados os critérios da OMS para definir suficiência iódica (mediana de UIC: 150-249 $\mu \mathrm{g} / \mathrm{L}$ entre as gestantes e 100-199 $\mu \mathrm{g} / \mathrm{L}$ para as não gestantes). Resultados: A mediana de UIC das gestantes estudadas esteve abaixo da recomendada (mediana $=137,7 \mu \mathrm{g} / \mathrm{L} ; 95 \% \mathrm{IC}=132,9-155,9)$ enquanto a das mulheres não grávidas se mostrou na faixa adequada (mediana $=190 \mu \mathrm{g} / \mathrm{L} ; 95 \% \mathrm{IC}=159,3-200,1$ ). Entre as gestantes, $57 \%$ apresentaram UIC < $150 \mu \mathrm{g} / \mathrm{L}$. Conclusões: Apesar de uma maior amostragem ser necessária para a confirmação desses achados, os resultados levantam preocupação quanto à suficiência iódica nas mulheres grávidas no Brasil, principalmente diante das novas determinações governamentais brasileiras quanto à redução das concentrações de iodo no sal de cozinha para $15-45 \mathrm{mg} / \mathrm{kg}$. Arq Bras Endocrinol Metab. 2014;58(3):282-7

\section{Descritores}

lodúria; suficiência iódica; tireoide; gestação; Brasil

\section{INTRODUCTION}

D regnancy is associated with substantial changes in 1 thyroid physiology, with high stress on iodine homeostasis (1). An adequate iodine intake during this phase is essential in order to prevent adverse events in mother and fetus, since moderate to severe iodine deficiency with consequent hypothyroxinemia during fetal development and childhood is related to irreversible brain damage, mental retardation, and neurological deficits $(2-5)$. 
During pregnancy, iodine demand is significantly higher than in non-pregnant women $(6,7)$. While the daily iodine requirement for non-pregnant women is at least $150 \mu \mathrm{g} /$ day, this requirement increases to $250 \mu \mathrm{g} /$ day in pregnant women in order to maintain adequate free thyroxine $\left(\mathrm{FT}_{4}\right)$ concentrations. This greater iodine requirement is due to an increase of about $50 \%$ of maternal thyroxine production, to the transfer of iodine to the fetus and to the increased renal iodine clearance $(7,8)$.

Median urinary iodine concentration (UIC) is the biochemical marker most frequently used to assess iodine deficiency in a population. The rationale is based on the observation that renal excretion corresponds to more than $90 \%$ of iodine losses and is positively correlated with nutritional intake (9). In addition to being a valuable diagnostic tool, it is an efficient, low-cost, harmless and technically simpler method than other tests used to determine iodine deficiency. For the overall population, adequate iodine nutrition is defined by a median UIC of at least $100 \mu \mathrm{g} / \mathrm{L}$ (with $<20 \%$ of the population having UIC $<50 \mu \mathrm{g} / \mathrm{L}$ ), while a median $\mathrm{UIC}=20-49 \mu \mathrm{g} / \mathrm{L}$ and a median $\mathrm{UIC}<20 \mu \mathrm{g} / \mathrm{L} \mathrm{rep}-$ resent moderate and severe iodine deficiency, respectively (10). A median UIC of 50-149 $\mu \mathrm{g} / \mathrm{L}$ has been established as mild to moderate iodine deficiency in pregnant women, with values of 150-249 $\mu \mathrm{g} / \mathrm{L}$ indicating iodine sufficiency, and values above $250 \mu \mathrm{g} / \mathrm{L}$ indicating excessive iodine intake (10).

Several countries have recently assessed iodine nutrition in pregnant women using UIC. It has been observed that, even though iodine intake is sufficient in school age children, deficiency occurs in pregnant women (11-14). These observations justify the need for constant monitoring in these at-risk populations. In Brazil, despite the presence of universal salt iodination for human consumption in order to guarantee an adequate intake of this micronutrient, there are no recent data about iodine sufficiency in the population (an evaluation by the Health Ministry is currently underway), and no studies have been conducted on pregnant women. Based on this, the objective of the present study was to assess iodine sufficiency in pregnant women from the northeastern region of the state of São Paulo, the most populous state in the nation.

\section{MATERIAL AND METHODS}

This was a cross-sectional observational study of pregnant women residing in Ribeirão Preto, São Paulo, Bra- zil, conducted from August 2008 to November 2009. The city of Ribeirão Preto is located in the Northeast region of the state of São Paulo, at a distance of $350 \mathrm{~km}$ from the sea. Its inhabitants have a reduced habit of fish and dairy product intake, and have difficult access to seafood. According to official 2010 data, Ribeirão Preto has 600,000 inhabitants and approximately 8,000 children are born in the city per year.

A total of 191 pregnant women consecutively receiving their first routine prenatal visit at primary care units participated in the study. Inclusion criteria were age greater than 18 years and gestational time of up to 14 weeks regardless of associated diseases, but with the absence of a history of thyroid disease. A $10-\mathrm{mL}$ venous blood sample and a $10-\mathrm{mL}$ urine sample were collected from each selected woman between 07:00 and 09:30 $\mathrm{h}$ after an 8 -hour fast, and frozen at $-70^{\circ} \mathrm{C}$ until the time for analysis. Information was obtained regarding the use of tobacco, food supplements and vitamins, and data were collected with a directed questionnaire for the detection of hypothyroidism on a clinical basis. Data on physical examination were also obtained including weight, height, palpation of the thyroid gland, heart rate, and systemic arterial pressure.

Plasma TSH, free thyroxine fraction $\left(\mathrm{FT}_{4}\right)$, total thyroxine fraction $\left(\mathrm{TT}_{4}\right)$, anti-thyroglobulin antibody (anti-Tg), and anti-thyroperoxidase antibody (antiTPO) were determined by chemoluminescence (Immulite 2000, DPC Cirrus Inc. Los Angeles, CA) in a single assay. The intra-assay errors calculated for TSH, $\mathrm{FT}_{4}$ and $\mathrm{TT}_{4}$ were $3.1 \%, 2.6 \%$ and $2.1 \%$ for $\mathrm{TSH}, \mathrm{FT}_{4}$ and $\mathrm{TT}_{4}$ concentrations in the ranges of $1.5 \mathrm{mIU} / \mathrm{L}$, $\mathrm{l} \mathrm{ng} / \mathrm{dL}$ and $9.5 \mu \mathrm{g} / \mathrm{dL}$, respectively. The interassay errors were $5.6 \%, 3.3 \%$ and $4.8 \%$ for TSH values of $0.2,3.8$ and $16.8 \mathrm{mIU} / \mathrm{L} ; 11.4 \%, 3.9 \%$ and $3.9 \%$ for $\mathrm{TT}_{4}$ values of $12.7,8.9$ and $13.7 \mu \mathrm{g} / \mathrm{dL}$; and 4.3 and $2.6 \%$ for $\mathrm{FT}_{4}$ values of 1.0 and $2.5 \mathrm{ng} / \mathrm{dL}$, respectively.

UIC was determined by the modified SandellKalthoff reaction $(15,16)$, with chloric acid being replaced with ammonia persulfate (17). The reference UIC value for pregnant women was considered on the basis of the international WHO/UNICEF/ ICCIDD criteria (10) as follows: median UIC $<150$ $\mu \mathrm{g} / \mathrm{L}$ was considered to represent iodine insufficiency, UIC $=150-249 \mu \mathrm{g} / \mathrm{L}$ to represent adequate values, UIC $=250-449 \mu \mathrm{g} / \mathrm{L}$ to represent more than adequate values, and UIC $=500 \mu \mathrm{g} / \mathrm{L}$ or more to represent excess urinary iodine. 
Fifty-eight non-pregnant and non-nursing women matched by age with the pregnant women, taking no food or vitamin supplement, and living in the city of Ribeirão Preto were invited to provide a urine sample for UIC determination, representing the control nonpregnant group.

Data are reported as medians or means $\pm \mathrm{SD}$. Statistical analysis was performed using the SSPS software. The Mann Whitney $U$-Test was used for group comparisons. The level of significance was set at $\mathrm{p}<0.05$ in all analyses.

The study was approved by the Ethics Committee of the University Hospital, School of Medicine of Ribeirão Preto-USP, and all subjects signed a written informed consent form to participate.

\section{RESULTS}

The mean $( \pm S D)$ age of the pregnant women was $25.7 \pm 5.6$ years, with a median of 25 years (range: 18-42 years). Mean gestational age at the time of evaluation was $9.7 \pm 2.9$ weeks, with a median of 9 weeks. Forty pregnant women (20.9\%) were smokers, and 39 $(20.4 \%)$ continued to smoke during pregnancy. Family history of thyroid diseases among $\mathrm{l}^{\text {st }}$-degree relatives was reported by $14.1 \%$ pregnant women. Thirty-

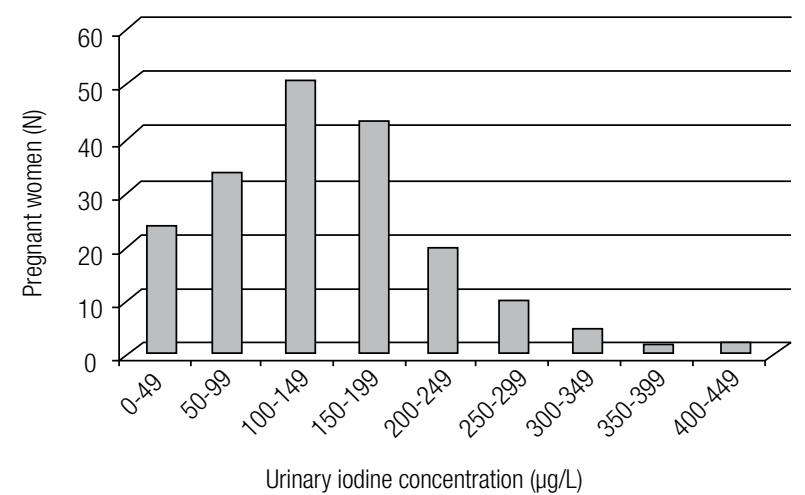

-three percent of them had already had a pregnancy, and $24 \%$ had a history of miscarriage preceding the current pregnancy. Three pregnant women had autoimmune diseases, 2 had rheumatoid arthritis, and 1 had vitiligo; $34 \%$ of them had mild goiter. None of them took supplements containing iodine in their composition.

Among the pregnant women, median UIC was $137.7 \mu \mathrm{g} / \mathrm{L}$ (range $=6.1-409.8$ ). A total of 109 pregnant women $(57 \%)$ presented iodinuria of less than $150 \mu \mathrm{g} / \mathrm{L}$, with $12.5 \%$ having iodinuria of less than 50 $\mu \mathrm{g} / \mathrm{L}, 19(9.9 \%)$ having iodinuria of more than 250 $\mu \mathrm{g} / \mathrm{L}$, and none having iodinuria exceeding $500 \mu \mathrm{g} / \mathrm{L}$.

The mean $( \pm \mathrm{SD})$ age of the non-pregnant and nonnursing women was $28.5 \pm 5$ years, median UIC was $190 \mu \mathrm{g} / \mathrm{L}($ range $=46.4-355.9)$. Nine of the women (15.5\%) had UIC < $100 \mu \mathrm{g} / \mathrm{L}$.

Figure 1 shows the histograms with the distribution of UIC values for both groups, showing an asymmetrical distribution, especially among pregnant women. Iodinuria median values differed significantly between pregnant and non-pregnant women $(\mathrm{p}=0.0018)$. Table 1 shows iodinuria and TSH, FT4, and TT4 values for the pregnant women studied. There was no association between iodinuria and these variables.

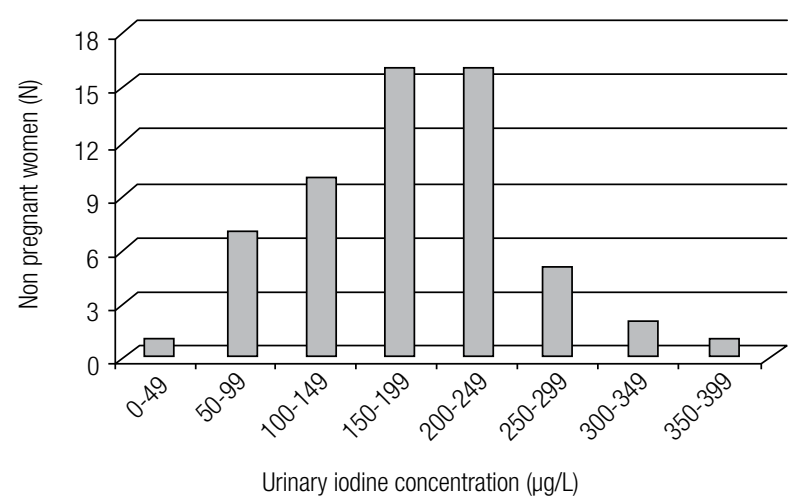

Figure 1. Histogram of the distribution of urinary iodine concentrations in pregnant $(N=191)$ and non-pregnant women $(N=58)$ from the city of Ribeirão Preto, SP, Brazil

Table 1. Iodinuria values and TSH, TT4 and FT4 concentrations in the pregnant women studied

\begin{tabular}{|c|c|c|c|c|c|c|c|c|c|c|c|c|}
\hline \multirow{2}{*}{ lodinuria ranges } & \multicolumn{3}{|c|}{ Iodinuria } & \multicolumn{3}{|c|}{ TSH (mIU/L) } & \multicolumn{3}{|c|}{$\mathrm{TT4}(\mu \mathrm{g} / \mathrm{dL})$} & \multicolumn{3}{|c|}{ FT4 (ng/dL) } \\
\hline & Mean & SD & Median & Mean & SD & Median & Mean & SD & Median & Mean & SD & Median \\
\hline $\begin{array}{l}>250 \mu \mathrm{g} / \mathrm{L} \\
\mathrm{N}=19(9,9 \%)\end{array}$ & 307.6 & 47.1 & 286.4 & 1.5 & 1.3 & 1.1 & 9.9 & 1.9 & 10.0 & 1.0 & 0.1 & 1.1 \\
\hline $\begin{array}{l}150-250 \mu g / L \\
N=63(33 \%)\end{array}$ & 190.6 & 27.7 & 188.1 & 1.8 & 1.5 & 1.4 & 9.8 & 2.0 & 10.0 & 1.1 & 0.2 & 1.1 \\
\hline $\begin{array}{l}<150 \mu \mathrm{g} / \mathrm{L} \\
\mathrm{N}=109(57 \%)\end{array}$ & 89.3 & 39.9 & 96.1 & 1.5 & 1.1 & 1.3 & 10.4 & 2.3 & 10.3 & 1.1 & 0.3 & 1.0 \\
\hline
\end{tabular}




\section{DISCUSSION}

The results of the present study indicate that a pregnant population from the northeastern region of the state of São Paulo is mildly iodine-deficient, with median UIC of $137.7 \mu \mathrm{g} / \mathrm{L}$. All pregnant women used iodinated salt, compulsorily sold in Brazil, but the concentration of iodine in salt for domestic use was not determined, which is a limitation of the study. The pregnant women studied did not consume other sources of iodine, such as multivitamin supplements containing iodine (although a few of them reported the use of polyvitamin and polymineral supplements, the formulations used did not contain iodine in their composition), suggesting that table salt was the only source of this mineral.

Since 1953, the Brazilian legislation has demanded the iodination of table salt, first limited to endemic areas, and then extended to the entire country in 1956, although with precarious control. From 1982 to 1992, the objective of the Program Against Endemic Goiter developed by the National Institute of Food and $\mathrm{Nu}^{-}$ trition (INAN) was to maintain salt iodination in the range from 10 to $30 \mathrm{mg}$ iodine $/ \mathrm{kg}$ salt, ensuring that the Brazilian population would receive iodine in an efficient manner. This program was discontinued in 1992 and in 1995 the National Program of Control of Iodine Deficiency Disorders started to be monitored by the National Agency of Sanitary Surveillance (Anvisa), with salt iodination being set at 40 to $60 \mathrm{mg}$ iodine $/ \mathrm{kg}$ salt. From 1998 to 2003, an excessive amount of iodine was offered to the Brazilian population due to the high iodine content in salt, as confirmed by the Thyromobil Project in $2001(18,19)$ which showed that $86 \%$ of Brazilian schoolchildren excreted more than $300 \mathrm{mg} / \mathrm{L}$ of iodine in urine, and more than $50 \%$ of the salt samples contained more than $60 \mathrm{mg}$ iodine $/ \mathrm{kg}$ salt. Thus, in 2003, the Anvisa standardized the ideal iodine concentration in salt for human consumption at 20 to $60 \mathrm{mg} /$ kg (20). The Health Ministry has recently started to finance the National Survey on the Impact of Salt Iodination (PNAISAL) in order to determine iodine sufficiency in the country, but the results of this evaluation are still pending. Nevertheless, Brazil is considered to be a country with more than adequate iodine intake (21). Recently (April/2013), the Anvisa decided to reduce iodine concentration to $15-45 \mathrm{mg} / \mathrm{kg}$ of salt (22) based on observations of the Brazilian Institute for Geography and Statistics (IBGE), which has stated that the salt intake of Brazilians was high, about 12 grams daily, due in part to the high consumption of industrial- ized products (www.ibge.gov.br). There are no literature data about iodinuria in Brazilian pregnant women.

In the present study, a comparison with non-pregnant and non-nursing women of the same age range demonstrated significantly higher values in the latter group, suggesting that iodine intake is sufficient in the Ribeirão Preto region. These data corroborate the findings of Alves and cols. (23) conducted in the same city, evaluating 300 schoolchildren from 2007 to 2008, who demonstrated that there is sufficiency iodine nutrition in the city, and even excessive iodine intake (median UIC values $>300 \mathrm{ug} / \mathrm{L}$ ) among schoolchildren of highest social level probably due to high intake of salt and processed foods.

Our data support those obtained by Marchioni and cols. (12) in the city of Rome, Italy, who detected a median of $74 \mu \mathrm{g} / \mathrm{L}$ (range: 17-243 $\mu \mathrm{g} / \mathrm{L}$ ) among pregnant women and of $182 \mu \mathrm{g} / \mathrm{L}$ (range: $85-340 \mu \mathrm{g} / \mathrm{L}$ ) in non-pregnant women, suggesting that even in urban areas with iodine-sufficient mothers, the fetuses are at risk of disorders caused by iodine insufficiency, such as miscarriage, prematurity, and inadequate development of fetal brain maturation.

A recent study conducted in the United States (24) compared the UIC of the overall American population during the 2005-2006 and 2007-2008 periods, and observed that median UIC was $164 \mu \mathrm{g} / \mathrm{L}$, being stable and similar to the values obtained in the large epidemiological study NHANES III in 1988-1994. Median UIC was $125 \mu \mathrm{g} / \mathrm{L}$ in pregnant women (95\% CI, 86198 ) with $56.9 \%$ of them showing UIC $<150 \mu \mathrm{g} / \mathrm{L}$. The authors concluded that iodine nutrition is adequate in the American population, but some groups, such as pregnant women, did not present sufficient iodine intake according to the WHO criteria.

Studies conducted in other countries (Northeastern region of England and Australia) have also shown that, in populations considered to be iodine sufficient at the time, $50 \%$ of pregnant women were found to have insufficient UIC (25).

These results, together with those obtained in the present study, indicate the need for iodine replacement in pregnant women during the prenatal period by means of food supplements containing iodine, even in areas of iodine sufficiency. This recommendation is based on the current consensus of the American Thyroid Association (26), which establishes that women should receive $150 \mu \mathrm{g} /$ day of supplemental iodine during pregnancy and nursing, and that all vitamin/ 
mineral preparations should contain $150 \mu \mathrm{g}$ of iodine. However, only $49 \%$ of the food supplements commercially sold in the United States contain iodine (27).

Although more than half the pregnant women studied had low UIC values, their mean TSH, TT4, and FT4 values were within the range expected for pregnant women and were similar to those of pregnant women with UIC values < $150 \mu \mathrm{g} / \mathrm{L}$, between 150 and 249 $\mu \mathrm{g} / \mathrm{L}$ and $>250 \mu \mathrm{g} / \mathrm{L}$. However, a high percentage of them had mild goiter at palpation.

The iodine concentration that may pose a risk to the intellectual development of a child has not been properly established. Brain damage is not directly related to the lack of iodine, but is indirectly related to it due to the ability of the thyroid of mother and child to synthesize the thyroid hormones in the presence of the amount of iodine offered. Recent controlled studies have shown that mild to moderate iodine deficiency impairs cognition $(5,28,29)$. It is also known that the deficiency of other nutrients and the effects of goiterinducing substances interfere with the enzymes and transporters used for thyroid hormone synthesis, and worsen the effects of iodine deficiency. One of them is thiocyanate, which can be ingested or be generated in the liver from cyanide in smokers (30). Deficient intake of iron and of other nutrients also contributes to the harmful effects of iodine deficiency $(31,32)$. In the present study, $20 \%$ of the pregnant women continued to smoke despite being informed about the dangers of the habit.

This was the first study to analyze iodinuria in Brazilian pregnant women. Based on our findings, pregnant women seen in the public health network have inadequate iodine concentrations. Appropriate monitoring of iodine concentrations in women at fertile age stratified according to social class, including a larger number of pregnant women, is necessary in order to consolidate these results. Additionally, it is necessary to establish the determinants of iodine nutrition among pregnant and nursing women in the country and to determine how iodine concentrations are modified during pregnancy.

Acknowledgments: we would like to thank Dr. Geraldo Duarte and Dr. Silvana M. Quintana for their assistance with clinical evaluations of pregnancy. The study was supported by Fundação de Amparo à Pesquisa do Estado de São Paulo (Fapesp) (Grant 2009/53296-9).

Disclosure: no potential conflict of interest relevant to this article was reported.

\section{REFERENCES}

1. Glinoer $D$. The regulation of thyroid function during normal pregnancy: importance of the iodine nutrition status. Best Pract Res Clin Endocrinol Metab. 2004;18:133-52.

2. Tai M.The devastating consequence of iodine deficiency. Southeast Asian JTrop Med Public Health. 1997;28(suppl 2):75-7.

3. Santiago-Fernandez $P$, Torres-Barahona R, Muela-Martínez JA, Rojo-Martínez G, García-Fuentes E, Garriga MJ, et al. Intelligence quotient and iodine intake: a cross-sectional study in children. $J$ Clin Endocrinol Metab. 2004;89:3851-7.

4. Boonstra AM, Jaiswal $\mathrm{N}$. lodine deficiency in pregnancy, infancy and childhood and its consequences for brain development. Best Pract Res Clin Endocrinol Metab. 2010;24:29-38.

5. Bath SC, Steer CD, Golding J, Emmett P, Rayman MP. Effect of inadequate iodine status in UK pregnant women on cognitive outcomes in their children: results from the Avon Longitudinal Study of Parents and Children (ALSPAC). Lancet. 2013;382(9889):331-7.

6. Glinoer $D$. The importance of iodine nutrition during pregnancy. Public Health Nutr. 2007;10:1542-6.

7. Zimmermann MB. lodine deficiency. Endocr Rev. 2009;3:376-408.

8. Berbel P, Obregón MJ, Bernal J, Escobar del Rey F, Morreale de Escobar G. lodine supplementation during pregnancy: a public health challenge. Trends Endocrinol Metab. 2007;18:338-43.

9. Delange F, Bürgi H, Chen ZP, Dunn JT. World status of monitoring iodine deficiency disorders control programs. Thyroid. 2002;12:915-24.

10. WHO, UNICEF, and ICCIDD. Assessment of the iodine deficiency disorders and monitoring their elimination, 3rd edition. Geneva: World Health Organization WHO/NHD/01.1; 2007.

11. Alvarez-Pedrerol M, Ribas-Fitó N, García-Esteban R, Rodriguez A, Soriano $D$, Guxens $M$, et al. lodine sources and iodine levels in pregnant women from an area without known iodine deficiency. Clin Endocrinol (Oxf). 2010;72:81-6.

12. Marchioni E, Fumarola A, Calvanese A, Piccirilli F, Tommasi V, Cugini $P$, et al. lodine deficiency in pregnant women residing in an area with adequate iodine intake. Nutrition. 2008;24:458-61.

13. Perrine CG, Herrick K, Serdula M, Sullivan KM. Some subgroups of reproductive age women in the United States may be at risk for iodine deficiency. J Nutr. 2010;140:1489-94.

14. Vanderpump MP, Lazarus JH, Smyth PP, Laurberg P, Holder RL, Boelaert K, et al. lodine status of UK schoolgirls: a cross-sectional survey. Lancet. 2011;377:2007-12.

15. Dunn JT, Crutchfield HE, Gutekunst R, Dunn AD. Two simple methods for mensuring iodine in urine. Thyroid. 1993;3:119-23.

16. Sandell ED, Kalthoff IM. Microdetermination of iodine by a catalytic method. Mikrochim Acta. 1937;1:9-25.

17. Esteves RZ. Determinação da excreção urinária de iodo em escolares brasileiros [thesis]. São Paulo: Universidade Federal de São Paulo; 1997.

18. Rossi AC, Tomimori E, Camargo R, Medeiros-Neto G. Searching for iodine deficiency disorders in schoolchildren from Brazil: the Thyromobil Project. Thyroid. 2001;11:661-3.

19. Pretell EA, Delange F, Hostalek U, Corigliano S, Barreda L, Higa $\mathrm{AM}$, et al. lodine nutrition improves in Latin America. Thyroid. 2004; $14: 590-9$.

20. Medeiros-Neto G. lodine nutrition in Brazil: where do we stand? Arq Bras Endocrinol Metab. 2009;53:470-4.

21. Camargo R, Tomimori E. Risk of iodine excess in Brazil. IDD Newsletter. 2009;1:31-7.

22. Resolução DA - RDC No. 23, de 24 de abril de 2013. Available from: http://www.in.gov.br/imprensa/visualiza/index.jsp?jornal=1 \&pagina $=55 \&$ data $=25 / 04 / 2013$. 
23. Alves, MLD, Duarte G, Navarro AM, Tomimori EK. Avaliação ultrassonográfica da tireoide, determinação da iodúria e concentração de iodo em sal de cozinha utilizado por escolares de Ribeirão Preto, São Paulo, Brasil. Arq Bras Endocrinol Metab. 2010;54:813-8.

24. Caldwell KL, Makhmudov A, Ely E, Jones RL, Wang RY. lodine status of the U.S. population, National Health and Nutrition Examination Survey, 2005-2006 and 2007-2008. Thyroid. 2011;21:419-27.

25. Delange F. The disorders induced by iodine deficiency. Thyroid. 1994;4:107-28.

26. Stagnaro-Green A, Abalovich M, Alexander E, Azizi F, Mestman J, Negro R, et al. Guidelines of the American Thyroid Association for the diagnosis and management of thyroid disease during pregnancy and postpartum. Thyroid. 2011;21:1081-125.

27. Leung AM, Pearce EN. The State of U.S. lodine Nutrition: How can we Ensure Adequate lodine for All? Thyroid. 2013;23:924-5.
28. Zimmermann MB, Connolly K, Bozo M, Bridson J, Rohner F, Grimci L. lodine supplementation improves cognition in iodine-deficient schoolchildren in Albania: a randomized, controlled, double-blind study. Am J Clin Nutr. 2006;83:108-14.

29. Gordon RC, Rose MC, Skeaff SA, Gray AR, Morgan KM, Ruffman T. lodine supplementation improves cognition in mildly iodine-deficient children. Am J Clin Nutr. 2009;90:1264-71.

30. Laurberg P, Cerqueira C, Ovesen L, Rasmussen LB, Perrild H, Andersen $\mathrm{S}$, et al. lodine intake as a determinant of thyroid disorders in populations. Best Pract Res Clin Endocrinol Metab. 2010;24:13-27.

31. Zimmermann MB. The influence of iron status on iodine utilization and thyroid function. Annu Rev Nutr. 2006;26:367-8.

32. Vanderpas J. Nutritional epidemiology and thyroid hormone metabolism. Annu Rev Nutr. 2006;26:293-322. 